\title{
Brain versus Reality: How Should Law Students Think?
}

\author{
Anis Widyawayi ${ }^{1}$, Ridwan Arifin $^{2 *}$, Rasdi Rasdi ${ }^{3}$ \\ 1,3 Doctoral Student, Universitas Diponegoro, Semarang, Indonesia \\ 2 Faculty of Law, Universitas Negeri Semarang, Indonesia \\ *Corresponding Email: ridwan.arifin@mail.unnes.ac.id
}

Abstract: Law students are expected to have special abilities in the field of legal science, either in oral or oral. But in fact, the analytical skills of law students are not comparable to other abilities. Based on preliminary research conducted by the Proposer Team, it shows that out of 200 law students surveyed (Students of the Faculty of Law, Semarang State University), only 10 have written and conducted scientific publications in both national and international journals. Meanwhile, of the 200 people stated that students' critical abilities and analytical thinking are important, 184 people said that discussion forums are mandatory for law students, but in fact, of these 184 people, only 2 people followed up on the results of the discussion. . In other words, discussions conducted by students were not followed up in various forms of scientific studies and publications that could be read by many people. This program provides facilities for law students in in-depth critical analysis studies and criminal case studies related to human rights. In this program, students are expected to be able to have good analytical skills both in oral and verbal forms. Partners in this program are the law student community at Semarang State University. This program is expected to be able to solve partners' problems in the lack of critical analytical skills and case studies of criminal law as well as scientific publication of legal research results. The output of this program is expected to create a sustainable and sustainable activity related to critical analysis and legal case studies.

Keywords: Critical Analysis; College student; Law Student Abilities; Case study; Criminal Case Studies

\section{How to cite:}

Widyawati, A., Arifin, R., \& Rasdi, R. (2021). Brain versus Reality: How Should Law Students Think?. Indonesian Journal of Advocacy and Legal Services, 3(1), 91-110. https://doi.org/10.15294/ijals.v3i1.42290 


\section{A. Introduction}

The development of student activists has become one of the issues that has been studied by many parties, especially in relation to the movement and its contribution to the progress of the nation. However, in addition to positive views on student activists, so far negative stereotypes and stigma have been attached to student activists related to their academic achievement and study period. Activist students are almost always associated with low academic performance and late graduation, or even dropping out. High academic achievement and passing studies on time for most students may also be for educators and education experts to be the two main standards of study success, but for activist students, the meaning of achievement is not just a high GPA or rapid graduation of study. ${ }^{1}$

Students as agents of change and agents of social control are actually the mouthpiece of the people. As a consequence, student assignments are not only studying and busy with assignments, but also being grounded to society. This is in accordance with the Tri Dharma of Higher Education which implies aspects of education, research and community service. From this concept, it can be seen clearly that the scope of students is study and society. However, sometimes student activists encounter obstacles in dividing time between academics and organizations. ${ }^{2}$

Research by DiPipi-Hoy, Jitendra, and Kern stated that the results of the study conducted showed that self-reporting or time management skills were often related to academic achievement. Lower management effectiveness creates stress and tension. Good time managers are planning and organizational. In addition, inefficient use of time, lack of control over time demands and insufficient amount of time are found to have a negative impact on individual psychology. ${ }^{3}$

Meanwhile, in the paradigm of social change systems both on values and structures in a revolutionary and evolutionary manner, student activities are influenced by social movements from the individual environment and

1 Anwar, K. (2012). Tidak Semata IPK, Tidak Sebatas Wisuda: Memahami Dinamika Motivasi Berprestasi Akademik Mahasiswa Aktivis. Skripsi. Yogyakarta: Universitas Gadjah Mada.

2 Barr, F. D., \& Harta, I. (2016). Analisis Manajemen Waktu Organisasi dan Kuliah Aktivis Mahasiswa Program Studi Pendidikan Matematika Universitas Muhammadiyah Surakarta. PRISMA, Prosiding Seminar Nasional Matematika IX(1): 280-285. Diakses dari https://journal.unnes.ac.id/sju/index.php/prisma/article/view/21484

3 DiPipi-Hoy, C., Jitendra, A. K., \& Kern, L. (2009). Effects of Time Management Instruction on Adolescents Ability to Self-Manage Time in a Vocational Setting. The Journal of Special Education 43(3): 145-159. 
social groups that are part of the individual. Social movements can appear in a variety of interests, such as changing the structure of social relationships, changing views of life, and fighting over political roles. ${ }^{4}$ Likewise, what happened with some of the dynamics of student activists at the Faculty of Law, Semarang State University (FH UNNES). Social changes that have in some cases triggered various conflicts, for example in the case of demonstrations in the campus environment against admission fees. ${ }^{5}$

According to Rollo May (1967) in Feist, J. \& Feist, GJ that people who are involved in conflict and the clash between ideals and reality that occur will deny destiny, lose their reason to "be" and have no direction. They walk without a goal or target. Then they will engage in behavior that makes them lose and destroy. They feel insignificant in a world that is increasingly dehumanizing individuals. This feeling of insignificance leads people to apathy and a state of decreased consciousness. ${ }^{6}$

Thus, according to Oley (2013), the tendency to conflict is a natural and very natural thing in the dynamics of student activists, however, the response and reaction to the conflict is very important to pay attention to reduce the negative impacts it causes. One of them, by providing sufficient space and a forum for the development of democracy in the campus environment, including the development of students' critical attitudes.

Tawakal emphasizes the critical attitude that exists in students, where according to him that a critical attitude is raised because there is a deviation, and like a problem, there must be a solution. According to him, a critical attitude is a solution, which is not just throwing arguments without concrete solutions. The critical attitude is not to bring down the opponent, but to build

4 Susan, N. (2009). Sosiologi Konflik dan Isu-isu Konflik Kontemporer. Jakarta: Kencana Prenada Media Group; Septiani, P. (2016). Orientasi Karakter Perilaku Aktivis Mahasiswa (Character Orientation of Students Activist Behavior). Jurnal Riset Mahasiswa Bimbingan dan Konseling 5(12): 636-646. Diakses dari http://journal.student.uny.ac.id/ojs/index.php/fipbk/article/viewFile/6248/6000

5 Anonymous. (2018). Tanggapan Rektor Unnes soal Demo Mahasiswa yang Berujung Ricuh. $\quad$ Liputan 6 edisi 8 Juni, diakses dari https://www.liputan6.com/regional/read/3554192/tanggapan-rektor-unnes-soal-demomahasiswa-yang-berujung-ricuh; Sugiyarto, S. (2018). Demo Mahasiswa Unnes Menolak Uang Pangkal Dilanjutkan Menginap di Depan Rektorat. TRIBUNNEWS edisi 5 Juni, diakses dari http://www.tribunnews.com/regional/2018/06/05/demo-mahasiswa-unnesmenolak-uang-pangkal-dilanjutkan-menginap-di-depan-rektorat; Budi, T. (2018). Demo Mahasiswa Universitas Negeri Semarang Tolak Uang Pangkal Berujung Rusuh. OKEZONE edisi 7 Juni, diakses https://news.okezone.com/read/2018/06/07/512/1908011/demo-mahasiswa-universitasnegeri-semarang-tolak-uang-pangkal-berujung-rusuh; Widiarto, A. (2018). Ratusan Mahasiswa Unnes Demo Tolak Uang Pangkal. Suara Merdeka, edisi 4 Juni, diakses dari https://www.suaramerdeka.com/news/baca/92227/ratusan-mahasiswa-unnes-demotolak-uang-pangkal

6 Feist, J. \& Feist, G.J. (2010). Teori Kepribadian, Edisi 7. Jakarta: Salemba Humanika. 
solidarity and togetherness. ${ }^{7}$ Critical is objective, as a student, the horizon of knowledge must be open to change and sensitive and assess something as not original, there must be concrete facts that support the argument and based on an objective view, not a subjective view that only benefits some groups. Critical attitudes are real or real, not fictitious things that are deliberately raised and made controversy, non-existent and solution-oriented, not creating new problems. Even according to Wae as an agent of change, students should also be critical and face this situation. By being critical, students' insights will increase. Their character will also be formed into a person who is wise in handling problems. ${ }^{8}$ One way is by utilizing the freedom to express thoughts as regulated in the 1945 Constitution Article 28E paragraph 2. Of course, by paying attention to ethics and using polite sentences.

Thus, the distribution of student critical attitudes must be directed to maximize student potential. This activity is expected to be able to provide solutions to partner problems (Student Activists of the Faculty of Law UNNES) in building critical attitudes through the development of sustainable publications.

The problems faced by partners, based on the results of a preliminary survey (of 55 student activists of the Faculty of Law UNNES, December 2019February 2020), showed $63.6 \%$ (35) agreed that the ability to be critical for student activity is needed for self-capacity building, however the survey results also showed that $52.7 \%$ (29) agreed that studies and discussions organized by student activists only ended in discussion forums without followup. In fact, the results of student discussions and studies are important as solutions to problems faced by the community, so that in practice, many of the solutions presented by student activists cannot be transferred to a more concrete form towards society. In fact, the critical level and publication of student activist thoughts, only $9,1 \%$ (5) who have published their thoughts, and $90.9 \%$ (50) have never published their thoughts at all. Thus, the publication improvement program as a forum for channeling critical attitudes for student activists of the UNNES Faculty of Law is very important to do.

The problems faced are based on the results of an initial survey of students (law student activists), where the Student Executive Board (BEM) of the Faculty of Law, Semarang State University (FH UNNES) is one of the

7 Tawakal, I. (2015). Kritis Pada Diri Mahasiswa, Untuk Perubahan. Kompasiana, edisi 15 Juni, diakses dari https://www.kompasiana.com/tautawtau/550b3ec3a33311b0142e39e1/kritis-pada-dirimahasiswa-untuk-perubahan

8 Wae, W. (2014). Membangun Sikap Kritis. Opini Online OKEZONE, edisi 1 Desember, diakses dari https://news.okezone.com/read/2014/12/01/65/1072809/membangun-sikapkritis 
student organizations at the faculty level. In 2020, the total members of the BEM FH UNNES Board of 2020 were 82 people, having several ministries, including Strategic Studies (KASTRAT), Interests and Talents (MIKAT), and Community Service (PENGMA). BEM FH UNNES also oversees several activities within the faculty. BEM FH UNNES also has several excellent national level programs, such as the Indonesian Legal BEM meeting, LAWBILITY activities, MARVELLAW, and other activities that support various student activities.

BEM FH UNNES also regularly conducts regular reviews and discussions, both thematically and incidentally. Various communities resulting from the discussions were formed, such as the Marun School, and so on. However, the results of the preliminary investigation carried out by the Chief Proposer, that until now, BEM FH UNNES did not yet have a forum for critical writing and scientific publications at both the local and national levels. This is of course a separate note for BEM FH UNNES as a forum for aspiration, advocacy, and study of community problems.

The results of a preliminary survey conducted by the Chief Proposer, on tracking the level of publication among student activists, with the number of respondents: 55 student activists, and conducted through an online questionnaire in December 2019-February 2020 indicated the following problems:

1. How often do you participate in discussion activities (both at UNNES and outside UNNES)

\begin{tabular}{lcc}
\hline Category & amount & Percentage (\%) \\
\hline Sometimes & 42 & 76.4 \\
Often & 11 & 20 \\
Never & 2 & 3,6 \\
\hline
\end{tabular}

2. How often do you comment on the latest issues, be it international, national, local or campus

\begin{tabular}{lcc}
\hline Category & amount & Percentage (\%) \\
\hline Sometimes & 35 & 63.6 \\
Often & 18 & 32.7 \\
Very often & 1 & 1.8 \\
Never & 1 & 1.8 \\
\hline
\end{tabular}

3. In discussion forums that you have participated in, have you been active in writing comments after that?

\begin{tabular}{lcc}
\hline Category & amount & Percentage (\%) \\
\hline Sometimes & 32 & 58.2 \\
Never & 21 & 38.2 \\
Always & 2 & 3,6 \\
\hline
\end{tabular}


A. Widyawati, R. Arifin, \& R. Rasdi

4. What media do you often use in making reviews of the results of these discussions?

\begin{tabular}{lcc}
\hline Category & amount & Percentage (\%) \\
\hline Online & 45 & 81.8 \\
Print & 10 & 10 \\
\hline
\end{tabular}

5. As a student activist, are communication skills and critical thinking important?

\begin{tabular}{lcc}
\hline Category & amount & Percentage (\%) \\
\hline Very important & 34 & 61.8 \\
Urgent & 21 & 38.2 \\
\hline
\end{tabular}

6. As a student activist, when there are recent issues that you need to criticize, what media or media do you use to criticize them for the first time?

\begin{tabular}{lcc}
\hline Category & amount & Percentage (\%) \\
\hline Discussion / Study Forum & 33 & 60 \\
Online media & 22 & 40 \\
\hline
\end{tabular}

7. As a student activist, have you ever written anything published (both online and in print)

\begin{tabular}{lcc}
\hline Category & amount & Percentage (\%) \\
\hline Never & 44 & 80 \\
Ever & 11 & 20 \\
\hline
\end{tabular}

8. Is the publication scientific in nature and based on the results of critical studies?

\begin{tabular}{lcc}
\hline Category & amount & Percentage (\%) \\
\hline Always & 4 & 7.3 \\
Sometimes & 18 & 32.7 \\
Never & 18 & 32.7 \\
Do not know & 15 & 27.3 \\
\hline
\end{tabular}

9. Do you feel that the results of student activist thematic studies / discussions have only ended in discussion forums?

\begin{tabular}{lcc}
\hline Category & amount & Percentage (\%) \\
\hline Strongly agree & 3 & 5.5 \\
Agree & 29 & 52.7 \\
Disagree less & 12 & 21.8 \\
Disagree & 7 & 12.7 \\
Do not know & 4 & 7.3 \\
\hline
\end{tabular}

10. Are critical writing skills required for student activists?

\begin{tabular}{lcc}
\hline Category & amount & Percentage (\%) \\
\hline It is necessary & 19 & 34.5 \\
Need & 35 & 63.6 \\
No need & 1 & 1.8 \\
\hline
\end{tabular}


11. Have you ever published critical thinking works in print?

\begin{tabular}{lcc}
\hline Category & amount & Percentage (\%) \\
\hline Yes & 4 & 7.3 \\
Not & 51 & 92.7 \\
\hline
\end{tabular}

12. If so: how many printed publications you have produced so far

\begin{tabular}{lcc}
\hline Category & amount & Percentage (\%) \\
\hline 0 Posts & 50 & 90.9 \\
1 posts & 4 & 7.3 \\
$2-4$ posts & 1 & 1.8 \\
\hline
\end{tabular}

13. Is your publication officially published (has an ISSN / ISBN)

\begin{tabular}{lcc}
\hline Category & amount & Percentage (\%) \\
\hline Never & 53 & 96.4 \\
Yes, all of them & 11 & 1.8 \\
Yes, but not all of them & 1 & 1.8 \\
\hline
\end{tabular}

14. Have you ever had critical writing training or something like that?

\begin{tabular}{lcc}
\hline Category & amount & Percentage (\%) \\
\hline Ever & 25 & 45.5 \\
Never & 30 & 54.5 \\
\hline
\end{tabular}

15. What did you get from the training?

\begin{tabular}{lcc}
\hline Category & amount & Percentage (\%) \\
\hline knowledge and direct application & 16 & 29.1 \\
Only knowledge without application & 12 & 21.8 \\
Only certificates & 4 & 7.3 \\
Did not get anything & 23 & 41.8 \\
\hline
\end{tabular}

\section{B. Method}

\section{Preliminary Program}

The implementation of this service begins with a preliminary activity, where in this stage, the Implementing Team identifies deeper and deeper into the problems faced by partners and the solutions that can be offered. The identification of problems in this stage is carried out through the method of observation and a questionnaire survey of the activity participants.

\section{Program Activities Method}

Activities in this service are carried out by the following methods, namely:

1) Workshop and Training

This activity is carried out to get more tangible results and clear outcomes, so that workshops and training are carried out regularly and continuously. The workshop and training involved several parties, including the Implementation Team, Team of Experts, Facilitators, and Participants. 
2) Simulation and Application

Simulations are carried out to provide experiences to partners through direct applications related to critical thinking and critical writing. Participants will be introduced to various media for distributing opinions and critical writings, both on a local and national scale.

3) Publication

This method is carried out in the final stage, where the output of this activity is the scientific publication of critical thinking students of the UNNES Faculty of Law in several well-known publishing media. In addition to book publication through these publishers, this activity also encourages student activists to publish critical thinking scientific articles on legal science, legal thinking, legal case studies, and legal studies in several national journals.

4) Accompaniment

The mentoring method is carried out to guard and assist partner participants on a regular basis in achieving the expected output targets. Assistance is carried out in a concrete and applicable manner, where partner participants will be assisted intensively and directly to solve the problems faced.

5) Case study

The case study method will be given to participants as a stimulus for a logical, structured, and critical flow of thinking on various problems in legal studies. The case studies offered vary according to the needs of partner participants.

\section{Result and Discussion}

1. Some Limitation Theories on the Research Program

\section{1) Constructivism Theory}

Constructivism is a psychological theory about human knowledge which states that humans build and name knowledge from their own experiences. ${ }^{9}$ Based on this theory, it becomes the basis for the teacher's actions in carrying out the learning process in order to facilitate students to construct their own concepts which in this research idea are in the form of geometric concepts. The teacher can provide a stimulus or stimulation in the form of questions or assignments to build student knowledge or the teacher asks students to ask students questions about the material to be studied through stimulation in the form of problems. In addition, the teacher can also

9 Rifa’i, A., \& Anni, C. T. (2009). Psikologi Belajar. Semarang: UNNES Press. 
provide opportunities for students to present their ideas in solving questions about what they understand.

\section{2) Critical thinking}

According to Mason, as quoted by Lunnerburg, "The concept of critical thinking may be one of the most significant trends in education relative to the dynamic relationship between how teachers teach and how students learn,"10 which means that critical thinking may become a trend. has been most influential in education in terms of how teachers teach and how students learn. Based on this statement, it is the teacher's duty to develop critical thinking skills in learning to hone both the teacher's ability to teach and how students learn.

According to Rhodes, as quoted by Colley et al, "Critical thinking is a habit of mind characterized by the comprehensive exploration of issues, ideas, artifacts, and events before accepting or formulating an opinion or conclusion"11 which means critical thinking. is a habit of mind characterized by comprehensive exploration of problems, ideas, artifacts, and events before accepting or formulating an opinion or conclusion. Augustine, as quoted by Fisher ${ }^{12}$ emphasizes important indicators of critical thinking skills, including:

a) State the truth of the question or statement

b) Analyze questions or statements;

c) Think logically;

d) Order, for example temporally, logically, causally;

e) Classifying, for example, ideas about objects;

f) Deciding, for example, whether there is sufficient evidence;

g) Predicting (including confirming predictions);

h) Theorize;

i) Understand others and themselves.

10 Lunenburg, F. C. (2011). Critical thinking and constructivism techniques for improving student achievement. In National Forum of Teacher Education Journal (Vol. 21, No. 3, pp. 1-9); Lunenburg, F. C. (2011). Theorizing about curriculum: Conceptions and definitions. International journal of scholarly academic intellectual diversity, 13(1), 1-6.

11 Colley, B. M., Bilics, A. R., \& Lerch, C. M. (2012). Reflection: A key component to thinking critically. The Canadian Journal for the Scholarship of Teaching and Learning, 3(1); Colley, B. M. (2012, January). Teaching social studies through the performing arts. In The Educational Forum (Vol. 76, No. 1, pp. 4-12). Taylor \& Francis Group.

12 Fisher, R. M. (2011). A critique of critical thinking: Towards a critical integral pedagogy of fearlessness. NUML Journal of Critical Inquiry, 9(2), 92. See also Snyder, L. G., \& Snyder, M. J. (2008). Teaching critical thinking and problem solving skills. The Journal of Research in Business Education, 50(2), 90; Fisher, A. (2008). Teaching comprehension and critical literacy: Investigating guided reading in three primary classrooms. Literacy, 42(1), 19-28. 
Based on these indicators, it can be concluded that critical thinking is a thought process that is based on ideas and thoughts in suggesting reasons to conclude and solve problems. The application in learning mathematics to think critically in solving problems means that students understand which concepts are used to solve problems by reasoning and thinking.

Ennis states that critical thinkers ideally have 12 critical thinking skills which are grouped into 5 aspects of critical thinking skills ${ }^{13}$, including:

a) Elementary clarification (provides a basic explanation) which includes:

- Focus on the question (can identify questions / problems, can identify possible answers, and what is thought does not come out of the problem). Analyze opinions (can identify conclusions from the problem, can identify reasons, can handle things that are not relevant to the problem).

- $\quad$ Trying to clarify an explanation through question and answer.

b) The basis for the decision (determine the basis for decision making) which includes:

- Consider whether the source can be trusted or not.

- Observe and consider a report on the results of observations.

c) Inference (draw conclusions) which includes:

- Deducing and considering the results of the deduction.

- Induce and consider the results of the induction.

- Make and determine value judgments.

d) Advanced clarification (provides further explanation) which includes:

- Define terms and consider those definitions.

- Identify assumptions.

e) Supposition and integration (estimate and combine) which includes:

- Consider reasons or questionable assumptions without including them in our thinking.

- Combining abilities and other characters in making decisions.

\section{3) Problem Based Learning}

Problem-based learning is learning that uses real problems that are not structured (ill-structured) and open-ended as a context or means for students to develop problem-solving and critical thinking skills and build new knowledge. ${ }^{14}$ This learning model directs students to think critically and

13 Ennis, R. (2011). Critical thinking: Reflection and perspective Part II. Inquiry: Critical thinking across the Disciplines, 26(2), 5-19. See also Ennis, R. H. (2008). Nationwide testing of critical thinking for higher education: Vigilance required. Teaching Philosophy, 31(1), 1-26.

14 Wood, D. F. (2003). Problem based learning. Bmj, 326(7384), 328-330. See also Hung, W., Jonassen, D. H., \& Liu, R. (2008). Problem-based learning. Handbook of research on 
actively during learning because students are guided to do thinking activities to solve problems, collect information, process, and conclude. In this model, the involvement of students during learning is emphasized because the teacher is only a facilitator who guides students during the learning process. The teacher's role in this learning model is to present a problem.

According to Padmavathy \& Mareesh, "Problem-Based Learning (PBL) describes a learning environment where problems drive the learning. That is, learning begins with a problem to be solved, and the problem is posed is such a way that students need to gain new knowledge before they can solve the problem", ${ }^{15}$ which means that PBL describes a learning environment where problems encourage learning. Thus, learning begins with a problem to be solved, and the problems that arise are such that students need to acquire new knowledge before they can solve problems. In the Problem Based Learning model, the focus of learning is on the selected problem so that students not only learn concepts related to problems but also scientific methods to solve these problems.

According to Inman "PBL is an instructional (and curricular) learnercentered approach that empowers learners to conduct research, integrate theory and practice, and apply knowledge and skills to develop a viable solution to a defined problem. Critical to the success of the approach is the selection of ill-structured problems (often interdisciplinary) and a tutor who guides the learning process and conducts a thorough debriefing at the conclusion of the learning experience" 16 , which means that PBL is a learning approach. which is centered on empowering students to conduct research, integrate theory and practice, and apply knowledge and skills to develop viable solutions. Other than that,

Problem Based Learning has the idea that learning can be achieved if educational activities are focused on authentic, relevant, and presented tasks or problems in a context. Problem-based learning (Problem Based Learning) is an innovative learning model that can provide active learning conditions for students because in order to learn a concept, students are given problems first, where these problems train students to think critically. An important aspect in Problem Based Learning is that learning starting with these

educational communications and technology, 3(1), 485-506; De Graaf, E., \& Kolmos, A. (2003). Characteristics of problem-based learning. International Journal of Engineering Education, 19(5), 657-662.

15 Padmavathy, R. D., \& Mareesh, K. (2013). Effectiveness of problem based learning in mathematics. International Multidisciplinary e-Journal, 2(1), 45-51.

16 Inman, T. F. (2011). The Effects of problem-based learning in math and science on high potential elementary school students. 
problems will determine the direction of learning in groups. This is supported by the statement from Crowley (2015:

According to Zabit, "PBL method will stimulate teaching and learning. Problem is the main focus of teaching and learning that will happen through problem solving activities. Declarative knowledge and skills that are gained through critical thinking skills will be applied to solve a problem"17, which means that PBL will stimulate teaching and learning activities with problems as the main focus of teaching and learning that will occur through problem solving activities. Declarative knowledge, and skills acquired through critical thinking skills will be applied to solve problems.

This is in line with what Norman et al said, as quoted by Makin ${ }^{18}$, "Curriculum within PBL reflects the situations students will find themselves in when working in the field and should demonstrate opportunity for problemsolving and critical thinking", which means the PBL curriculum reflects the situation students will find themselves in while working in the field and must demonstrate opportunities for problem solving and critical thinking. In addition, according to Surif et al, "PBL produces graduates who have the skills to solve problems and also possess analytical and critical thinking"19, which means that PBL produces graduates who have the ability to solve problems and also have analytical and critical thinking.

From some of the above, it is found that the PBL model used in learning sharpens and supports students' critical thinking skills. According to Pluck et al, "In recent years more complex teaching methods have been adapted for use within second language teaching that involved evoking student curiosity. The two primary forms are task-based learning (TBL) and Problem Based Learning (PBL)"20, which means teaching methods that involve curiosity, one of which is the PBL model. From this statement, it can be found that learning with the PBL model emphasizes student activeness in learning which is indicated by students' curiosity in learning.

17 Zabit, M. N. M. (2010). Problem-based learning on students critical thinking skills in teaching business education in Malaysia: A literature review. American Journal of Business Education (AJBE), 3(6), 19-32.

18 Makin, D. A. (2016). A descriptive analysis of a problem-based learning police academy. Interdisciplinary Journal of Problem-Based Learning, 10(1), 2.

19 Surif, J., Ibrahimb, N. H., \& Mokhtarc, M. (2013). Implementation of problem based learning in higher education institutions and its impact on students' learning. PBL Across Cultures, 66 .

20 Pluck, G., \& Johnson, H. L. (2011). Stimulating curiosity to enhance learning. GESJ: Education Sciences and Psychology, 2. 


\section{How Critical Thinking Improve Law Students Ability?}

Thinking skills are an indispensable ability in facing life's challenges. These skills include critical thinking skills, creative thinking and problem solving abilities. ${ }^{21}$ The ability to think critically is an ability that is indispensable for a person to be able to face various problems faced in social and personal life. There are several definitions of critical thinking. Facione states that critical thinking is self-regulation in deciding something that results in interpretation, analysis, evaluation, and inference, as well as an explanation using evidence, concept, methodology, criteria, or contextual considerations on which to make decisions. ${ }^{22}$ Choy \& Cheah defines critical thinking as a complex process that requires high-level cognitive processing of information. ${ }^{23}$ Ennis adds that critical thinking is the ability to think reflective and reasoned that is focused on what is believed or done. Critical thinking skills include basic clarification skills, basic decision making, concluding, providing further explanation, estimating, and integrating, as well as additional abilities. ${ }^{24}$

A critical thinker is able to analyze and evaluate every information he receives. This is in line with the opinion of Duron, et. al., which states that critical thinkers are able to analyze and evaluate information, raise vital questions and problems, formulate these questions and problems clearly, collect and assess relevant information using abstract, open-minded ideas, and communicate them with effective. ${ }^{25}$ Jie added that critical thinkers are able to criticize, ask, evaluate, and reflect on the information obtained. ${ }^{26}$

Teaching students to think critically is one of the main goals of education. ${ }^{27}$ As an educator, a teacher must be able to create learning that is

21 Kalelioglu, F., \& Gülbahar, Y. (2014). The Effects of Teaching Programming via Scratch on Problem Solving Skills: A Discussion from Learners' Perspective. Informatics in Education, 13(1), 33-50.

22 Facione, P. A. (2011). Critical thinking: What it is and why it counts. Insight ssessment, 2007 (1), 1-23.

23 Choy, S., \& Delahaye, B. (2011). Partnerships between universities and workplaces: some challenges for work-integrated learning. Studies in Continuing Education, 33(2), 157-172.

24 Ennis, R. (2011). Critical thinking: Reflection and perspective Part II. Inquiry: Critical thinking across the Disciplines, 26(2), 5-19. See also Ennis, R. H. (2008). Nationwide testing of critical thinking for higher education: Vigilance required. Teaching Philosophy, 31(1), 1-26.

25 Duron, R., Limbach, B., \& Waugh, W. (2006). Critical thinking framework for any discipline. International Journal of Teaching and Learning in Higher Education, 17(2), 160-166.

26 Jie, L. O. U. (2011). Teaching English Newspaper Reading to Develop Students' Critical Thinking Skills [J]. Journal of Zhejiang Shuren University (Humanities and Social Sciences), 3. See also Zhou, J., Jiang, Y., \& Yao, Y. (2015). The Investigation on Critical Thinking Ability in EFL Reading Class. English Language Teaching, 8(1), 83-94.

27 Kazempour, E. (2013). The effects of inquiry-based teaching on critical thinking of students. Journal of Social Issues \& Humanities, 1(3), 23-27; Kalelioğlu, F., \& Gülbahar, 
able to train students' critical thinking skills to find learning information independently and actively create cognitive structures in students (Patonah, 2014). Efforts to form optimal students' critical thinking skills require interactive classes, students are seen as thinkers, not someone being taught, and teachers act as mediators, facilitators, and motivators who help students in learning not teaching.

In this program, the measured critical thinking skills of participants consist of six indicators which are translated into 13 aspects. The instrument is in the form of 15 description questions. Students' answers were then categorized into four categories, namely true (B), partially correct (C), partially incorrect (K), and incorrect (S).

The results of this program indicate that of the 15 questions tested on the participants, it turns out that they have varied categories in each aspect tested. Students 'answers are spread out into four categories, namely categories B, C, K, and S. The results of the analysis of students' answers can be seen in Table 3.1.

The results of the category analysis of the answers to students' critical thinking skills in each aspect varied widely. The aspect of identifying or structuring questions, category $B$ is very high. This shows that students have excellent abilities in composing questions. The sentence structure of the questions made by the students was very good and in accordance with the specified topic. The aspect of analyzing conclusions is dominated by category C. This shows that students' ability to identify conclusions is still low. Students are able to identify truth or error to the conclusions presented, but students are less able to provide explanations that support these conclusions. Aspects of identifying and overcoming irrelevance, dominated by $\mathrm{C}$ aspects. Students are able to identify mistakes, but students have not been able to explain how to overcome this irrelevance. The why aspect is dominated by category B. Students are able to make questions and give answers well and correctly. Reputation aspects, dominated by category K, students are able to choose or determine reputable sources but have not been able to provide reasons for choosing such reputable sources. The aspect of short intervals between observations and reports, spread across all categories and dominated by category $\mathrm{S}$. This is because students do not understand time intervals well. The logic class aspect is dominated by category C. Students are able to deduce, but have not been able to provide an explanation regarding the deductions

Y. (2014). The effect of instructional techniques on critical thinking and critical thinking dispositions in online discussion. Journal of Educational Technology \& Society, 17(1), 248 258; Mahanal, S., Zubaidah, S., Sumiati, I. D., Sari, T. M., \& Ismirawati, N. (2019). RICOSRE: A Learning Model to Develop Critical Thinking Skills for Students with Different Academic Abilities. International Journal of Instruction, 12(2), 417-434. 
made. Generalizing aspects are spread over categories C, K, and S. Students are able to generalize a data but do not provide an explanation of the conclusions made. The aspect of the consequences of accepting or rejecting a decision is dominated by category B. Students are able to provide explanations for decision making or rejection. The definition aspect is dominated by category C. Students are able to make definitions but they are still not precise. Aspects of assumptions, almost all students' answers are in category $\mathrm{K}$. There are no answers in category B or C. Aspects of making and considering decisions, spread across all categories. Categories B, C, and K are evenly distributed and category $\mathrm{S}$ has only two student answers. This shows that students' critical thinking skills in this aspect are still low. The aspect follows the steps of problem solving, almost all students 'answers are in category B, only two students' answers are in category S.

Table 3.1. Results of Participant's Answer Analysis

\begin{tabular}{llcccc}
\hline \multirow{2}{*}{ No. Aspek } & & \multicolumn{4}{c}{ Kategori } \\
\cline { 3 - 6 } & & $\mathbf{B}(\%)$ & $\mathbf{C ~ ( \% )}$ & $\mathbf{K}(\%)$ & $\mathbf{S ~ ( \% )}$ \\
\hline 1 & Mengidentifikasi atau menyusun pertanyaan & 89,6 & 10,3 & & \\
\hline 2 & Menganalisis kesimpulan & 27,6 & 41,4 & 27,6 & \\
\hline 3 & Mengidentifikasi dan mengatasi ketidakrelevanan & 27,6 & 51,7 & 17,2 & 0,3 \\
\hline 4 & Mengapa & 62,1 & 20,7 & 17,2 & \\
\hline 5 & Mengapa & 75,8 & 10,3 & 13,8 & \\
\hline 6 & Reputasi & 0,3 & 17,2 & 58,6 & 17,2 \\
\hline 7 & Interval yang pendek antara observasi dan laporan & 10,3 & 6,8 & 34,5 & 48,3 \\
\hline 8 & Kelas logika & 6,8 & 79,3 & 13,8 & \\
\hline 9 & Menggeneralisasikan & & 37,8 & 48,3 & 13,8 \\
\hline 10 & Konsekuensi menerima atau menolak keputusan & 68,9 & 31,0 & & \\
\hline 11 & Definisi & 24,1 & 65,5 & 10,3 & \\
\hline 12 & Menilai kebenaran asumsi & & & 93,1 & 6,8 \\
\hline 13 & Membuat dan mempertimbangkan keputusan & 27,6 & 31,0 & 34,5 & 6,8 \\
\hline 14 & Mengikuti langkah-langkah penyelesaian masalah & 93,1 & 6,8 & & \\
\hline 15 & Mengikuti langkah-langkah penyelesaian masalah & 93,1 & 6,8 & & \\
\hline
\end{tabular}

\section{Conclusion}

At this stage, this program concludes that the ability to analyze cases and think critically of students in analyzing various criminal law cases is often trapped in case facts and legal instruments. Participants did not see various other legal events comprehensively. This training improves students' 
critical thinking skills in analyzing cases through various methods, one of which is problem-based learning.

\section{E. Acknowledgments}

Authors express the thankfulness to all parties involved on this research and to all faculty member of Faculty of Law Universitas Negeri Semarang, as well as all research team. Authors also express thankfulness to Student Staff at this research: Raden Muhammad Arvy Ilyasa and Septian Eka Adiyatma who support this research.

\section{F. Declaration of Conflicting Interests}

The authors state that there is no potential conflict of interest in the research, authorship, and/or publication of this article.

\section{G. Funding}

Universitas Negeri Semarang through the Faculty of Law Research Grants scheme.

\section{H. References}

Anonymous. (2018). Tanggapan Rektor Unnes soal Demo Mahasiswa yang Berujung Ricuh. Liputan 6 edisi 8 Juni, diakses dari https://www.liputan6.com/regional/read/3554192/tanggapan-rektorunnes-soal-demo-mahasiswa-yang-berujung-ricuh

Anwar, K. (2012). Tidak Semata IPK, Tidak Sebatas Wisuda: Memahami Dinamika Motivasi Berprestasi Akademik Mahasiswa Aktivis. Skripsi. Yogyakarta: Universitas Gadjah Mada.

Barr, F. D., \& Harta, I. (2016). Analisis Manajemen Waktu Organisasi dan Kuliah Aktivis Mahasiswa Program Studi Pendidikan Matematika Universitas Muhammadiyah Surakarta. PRISMA, Prosiding Seminar Nasional Matematika IX(1): 280-285. Diakses dari https://journal.unnes.ac.id/sju/index.php/prisma/article/view/21484

Budi, T. (2018). Demo Mahasiswa Universitas Negeri Semarang Tolak Uang Pangkal Berujung Rusuh. OKEZONE edisi 7 Juni, diakses dari https://news.okezone.com/read/2018/06/07/512/1908011/demomahasiswa-universitas-negeri-semarang-tolak-uang-pangkalberujung-rusuh 
Choy, S., \& Delahaye, B. (2011). Partnerships between universities and workplaces: some challenges for work-integrated learning. Studies in Continuing Education, 33(2), 157-172.

Colley, B. M. (2012, January). Teaching social studies through the performing arts. In The Educational Forum (Vol. 76, No. 1, pp. 4-12). Taylor \& Francis Group.

Colley, B. M., Bilics, A. R., \& Lerch, C. M. (2012). Reflection: A key component to thinking critically. The Canadian Journal for the Scholarship of Teaching and Learning, 3(1)

De Graaf, E., \& Kolmos, A. (2003). Characteristics of problem-based learning. International Journal of Engineering Education, 19(5), 657662.

DiPipi-Hoy, C., Jitendra, A. K., \& Kern, L. (2009). Effects of Time Management Instruction on Adolescents Ability to Self-Manage Time in a Vocational Setting. The Journal of Special Education 43(3): 145-159.

Duron, R., Limbach, B., \& Waugh, W. (2006). Critical thinking framework for any discipline. International Journal of Teaching and Learning in Higher Education, 17(2), 160-166.

Ennis, R. (2011). Critical thinking: Reflection and perspective Part II. Inquiry: Critical thinking across the Disciplines, 26(2), 5-19.

Ennis, R. H. (2008). Nationwide testing of critical thinking for higher education: Vigilance required. Teaching Philosophy, 31(1), 1-26.

Facione, P. A. (2011). Critical thinking: What it is and why it counts. Insight ssessment, 2007 (1), 1-23.

Feist, J. \& Feist, G.J. (2010). Teori Kepribadian, Edisi 7. Jakarta: Salemba Humanika.

Fisher, A. (2008). Teaching comprehension and critical literacy: Investigating guided reading in three primary classrooms. Literacy, 42(1), 19-28.

Fisher, R. M. (2011). A critique of critical thinking: Towards a critical integral pedagogy of fearlessness. NUML Journal of Critical Inquiry, 9(2), 92.

Inman, T. F. (2011). The Effects of problem-based learning in math and science on high potential elementary school students.

Jie, L. O. U. (2011). Teaching English Newspaper Reading to Develop Students' Critical Thinking Skills [J]. Journal of Zhejiang Shuren University (Humanities and Social Sciences), 3.

Kalelioğlu, F., \& Gülbahar, Y. (2014). The effect of instructional techniques on critical thinking and critical thinking dispositions in online discussion. Journal of Educational Technology \& Society, 17(1), 248258.

Kalelioglu, F., \& Gülbahar, Y. (2014). The Effects of Teaching Programming via Scratch on Problem Solving Skills: A Discussion from Learners' Perspective. Informatics in Education, 13(1), 33-50.

Kazempour, E. (2013). The effects of inquiry-based teaching on critical thinking of students. Journal of Social Issues \& Humanities, 1(3), 23-27. 
Lunenburg, F. C. (2011). Critical thinking and constructivism techniques for improving student achievement. In National Forum of Teacher Education Journal (Vol. 21, No. 3, pp. 1-9)

Lunenburg, F. C. (2011). Theorizing about curriculum: Conceptions and definitions. International journal of scholarly academic intellectual diversity, 13(1), 1-6.

Mahanal, S., Zubaidah, S., Sumiati, I. D., Sari, T. M., \& Ismirawati, N. (2019). RICOSRE: A Learning Model to Develop Critical Thinking Skills for Students with Different Academic Abilities. International Journal of Instruction, 12(2), 417-434.

Makin, D. A. (2016). A descriptive analysis of a problem-based learning police academy. Interdisciplinary Journal of Problem-Based Learning, 10(1), 2.

Padmavathy, R. D., \& Mareesh, K. (2013). Effectiveness of problem based learning in mathematics. International Multidisciplinary $e$ Journal, 2(1), 45-51.

Pluck, G., \& Johnson, H. L. (2011). Stimulating curiosity to enhance learning. GESJ: Education Sciences and Psychology, 2.

Rifa'i, A., \& Anni, C. T. (2009). Psikologi Belajar. Semarang: UNNES Press.

Snyder, L. G., \& Snyder, M. J. (2008). Teaching critical thinking and problem solving skills. The Journal of Research in Business Education, 50(2), 90.

Sugiyarto, S. (2018). Demo Mahasiswa Unnes Menolak Uang Pangkal Dilanjutkan Menginap di Depan Rektorat. TRIBUNNEWS edisi 5 Juni, diakses dari http://www.tribunnews.com/regional/2018/06/05/demomahasiswa-unnes-menolak-uang-pangkal-dilanjutkan-menginap-didepan-rektorat

Surif, J., Ibrahimb, N. H., \& Mokhtarc, M. (2013). Implementation of problem based learning in higher education institutions and its impact on students' learning. PBL Across Cultures, 66.

Susan, N. (2009). Sosiologi Konflik dan Isu-isu Konflik Kontemporer. Jakarta: Kencana Prenada Media Group; Septiani, P. (2016). Orientasi Karakter Perilaku Aktivis Mahasiswa (Character Orientation of Students Activist Behavior). Jurnal Riset Mahasiswa Bimbingan dan Konseling 5(12): 636-646. Diakses dari http://journal.student.uny.ac.id/ojs/index.php/fipbk/article/viewFile/624 $8 / 6000$

Tawakal, I. (2015). Kritis Pada Diri Mahasiswa, Untuk Perubahan. Kompasiana, edisi 15 Juni, diakses dari https://www.kompasiana.com/tautawtau/550b3ec3a33311b0142e39e1/k ritis-pada-diri-mahasiswa-untuk-perubahan

Wae, W. (2014). Membangun Sikap Kritis. Opini Online OKEZONE, edisi 1 Desember, diakses dari https://news.okezone.com/read/2014/12/01/65/1072809/membangunsikap-kritis

Widiarto, A. (2018). Ratusan Mahasiswa Unnes Demo Tolak Uang Pangkal. Suara Merdeka, edisi 4 Juni, diakses dari 
https://www.suaramerdeka.com/news/baca/92227/ratusan-mahasiswaunnes-demo-tolak-uang-pangkal

Wood, D. F. (2003). Problem based learning. Bmj, 326(7384), 328-330. See also Hung, W., Jonassen, D. H., \& Liu, R. (2008). Problem-based learning. Handbook of research on educational communications and technology, 3(1), 485-506.

Zabit, M. N. M. (2010). Problem-based learning on students critical thinking skills in teaching business education in Malaysia: A literature review. American Journal of Business Education (AJBE), 3(6), 19-32.

Zhou, J., Jiang, Y., \& Yao, Y. (2015). The Investigation on Critical Thinking Ability in EFL Reading Class. English Language Teaching, 8(1), 83-94.

\section{ABOUT AUTHOR(S)}

Anis Widyawati, S.H., M.H is a Doctoral Candidate of Universitas Diponegoro Semarang Indonesia. She also a Lecturer at Faculty of Law Universitas Negeri Semarang, Indonesia. Some of her recent publications such as Masalah Yuridis Tidak Ditetapkannya Kualifikasi Delik Dalam Ketentuan Pidana Pada Undang-Undang Yang Disahkan Dalam Kurun Waktu 2015-2019 (Jurnal Muara Ilmu Sosial, Humaniora, dan Seni, 2021), When Students Fight Corruption: A Portrait of Anti-Corruption Education for Elementary School Students (The Indonesian Journal of International Clinical Legal Education, 2021), and Police Intervention in Corruption Prevention (Advances in Police Science Research Journal, 2021).

Ridwan Arifin, S.H., LL.M., is a a Lecturer at Faculty of Law Universitas Negeri Semarang, Indonesia. He obtained a Bachelor Degree of Law from Universitas Negeri Semarang and Master of Laws from Universitas Gadjah Mada.

Rasdi, S.Pd. M.H is a Doctoral Candidate of Universitas Diponegoro Semarang Indonesia. He also a Lecturer at Faculty of Law Universitas Negeri Semarang, Indonesia. Some his recent publications such as Social Response of Legal Prevention For Cyberbullying To Children (A Comparative Studies On Cyberbullying To Children Of Indonesia And Thailand) (South East Asia Journal of Contemporary Business, Economics and Law, 2021) and Covid-19 and Human Rights: The Capture of the Fulfilment of Rights During the Covid Outbreaks (Unnes Law Journal, 2020). 


\section{Quote}

\section{Whenever we hear an opinion and believe it, we make an agreement, and it becomes part of our belief system}

\section{Miguel Ruiz}

The Four Agreements: A Practical Guide to Personal Freedom 